\title{
Design and Analysis of a Solar Powered Absorption Refrigeration System for Cooling a House in Isparta Province
}

\author{
Bengi Gozmen Sanli \\ Mersin University, Faculty of Engineering, Department of Mechanical Engineering, 33343, MERSIN, TURKEY
}

ORCID: B. Gozmen (0000-0001-6805-2454)

\begin{abstract}
In the present study, cooling of a duplex house placed in Isparta province by using solar-powered single effect absorption refrigeration system, which uses water-lithium bromide $\left(\mathrm{H}_{2} \mathrm{O}-\mathrm{LiBr}\right)$ mixture, was evaluated in details. Firstly, the cooling load of the house was determined as $19.34 \mathrm{~kW}$. In order to provide the cooling load of the house $(19.34 \mathrm{~kW})$, the heat required for the generator was calculated as $26.76 \mathrm{~kW}$, and the required collector surface area was determined by considering different types of collectors (flat plate and vacuum tube) to meet this heat capacity. In order to provide the cooling load of the house, the required surface area for the vacuum tube collectors was calculated as $10.32 \mathrm{~m}^{2}$ while it was found as $25.95 \mathrm{~m}^{2}$ for the flat plate collectors. It was concluded that the usage of vacuum tube collector with $57.9 \%$ efficiency is more appropriate since the required collector surface area is $15,63 \mathrm{~m}^{2}$ less than the required collector surface area for flat plate collector.
\end{abstract}

Keywords: Solar energy, cooling performance coefficient (COP),cooling load, absorption refrigeration system

\section{INTRODUCTION}

The energy demand on earth is increasing with growing world population. New energy sources have been investigated on alternative fuels to replace with fossil fuels due to the reduction of fossil fuel consumption and harmful emissions into the environment. Solar energy is the most important source in the renewable energy sources. Turkey is one of the favorable countries in terms of solar energy potential and Turkey has taken part in the region called as sun belt [1] Due to these reasons, solar energy has been used in several applications such as solar cells, absorption refrigeration systems, etc. Solar powered absorption refrigeration system discovered by Ferdinand Carre [2] is preferred for cooling in summer season. This system requires very low or no electricity input for the same cooling capacity and physical dimensions of an absorption refrigeration system is smaller than those of different refrigeration systems as adsorption refrigeration systems. These systems play an important role in the sustainability of energy and reduce the energy requirements, cooling cost and $\mathrm{CO}_{2}$ emission $[3,4]$. The absorbtion refrigeration systems are widely used in sever$\mathrm{al}$ areas owing to their advantages. Many researchers from various countries have studied on solar powered absorption refrigeration system due to the need for comfort cooling of buildings with high rate of availability of solar energy. Yilmazoğlu [6] carried out thermodynamic analysis of a single acting solar powered absoption refrigeration system (SPAR) using $\mathrm{H}_{2} \mathrm{O}-\mathrm{LiBr}$ as working fluid. Öztürk [6] performed a theoretical thermodynamic system on a SPAR system working with $\mathrm{NH}_{3}-\mathrm{H}_{2} \mathrm{O}$ fluid pair. Ghaddar et al [7] represented a modelling and simulation of a solar powered absorption refrigeration system for Beirut. The results of their study indicated that the montly solar fraction for cooling process was the function of solar collector surface area and storage tank capacity. Daşkın and Aksoy [1] studied on the cooling and air conditioning of additional building of Engineering Faculty of Inönü University by using solar energy supported absorption cooling system. They used $\mathrm{LiBr}-\mathrm{H}_{2} \mathrm{O}$ as the working fluid pair and they created the suitable system model by simulation. The performance analysis of a SPAR system used in Mersin province was performed by Şahin et al. [8]. They designed a $\mathrm{NH}_{3}-\mathrm{H}_{2} \mathrm{O}$ SPAR system using vacuum tube solar collectors and they analyzed the system. For the analysis, they used weather temperature and solar radiation value of Mersin province. Li et al. [9] studied on the experimental performance of a single-effect $\mathrm{H}_{2} \mathrm{O}-\mathrm{LiBr}$ absorption refrigeration system (of $23 \mathrm{~kW}$ refrigeration capacity) driven by a parabolic trough collector of aperture area $56 \mathrm{~m}^{2}$ for air
${ }^{*}$ Corresponding authour

Email: bengigozmen@mersin.edu.tr
European Mechanical Science, September 2019; 3(3): 112-117 doi: https://doi.org/10.26701/ems.588646

Received: July 8, 2019

Accepted: August 21, 2019 
conditioning of a $102 \mathrm{~m}^{2}$ meeting room located in Kunming, China. They investigated appropriate methods for improving the cooling performance. A solar powered absorption cooling system was modelled for Cyprus with TRNSYS simulation program by Florides et al. [10] and they examined economic performance of this system. They showed that the SPAR system worked with maximum performance when the auxiliary boiler thermostat was set as $87^{\circ} \mathrm{C}$, Moreover, it can be said that the energy of $84.240 \mathrm{MJ}$ required for cooling and 41.243 MJ were supplied for hot water production. $\mathrm{Xu}$ et al [11] performed a study on a new solar powered absorption refrigeration (SPAR) system with advanced energy storage technology. This advanced energy storage technology meant the variable mass energy transformation and storage (VMETS) technology. The results of this study showed that the COP of this system can increase to 0.7525 cooling air) or 0.7555 (cooling water) and the required solar collector area was calculated as $66 \mathrm{~m}^{2}$ for cooling air and $62 \mathrm{~m}^{2}$ for cooling water. Many researchers as Ali et al [12] and Ramesh et al. [13] have focused on solar powered absorption refrigeration systems due to its economic and ecolocial applications by combining the need for comfort and effective cooling of buildings. Bozkaya et al. [14] investigated to provide the required cooling load of İzmir province at a summer season. They used a single acting SPAR system using $\mathrm{NH}_{3}-\mathrm{H}_{2} \mathrm{O}$. In order to supply heat given to generator, proper collector area and collector type were determined. Özay [15] designed a solar powered absorption refrigeration system by using a parabolic solar collector for july in Isparta province. The COP and usability of the system were investigated. A solar powered $\mathrm{NH}_{3}-\mathrm{H}_{2} \mathrm{O}$ absorption cooling system was investigated by Stanciu et al.[16] They focused on the the best sizing of a solar-storage part of the global system for the longest possible daily operation in July, at $44.25^{\circ}$ $\mathrm{N}$ latitude. They used the meteorogical data generated by Meteonorm software. They revealed that there is a specific storage tank dimension associated to a specific PTC dimension that could ensure the longest continuous operation of the ACS. When an initial solar start-up was considered, the initial temperature of storage tank water was closed to the ambient one. The longest continuous operation of the $\mathrm{NH}_{3}-$ $\mathrm{H}_{2} \mathrm{O}$ cooling system was obtained for a $10 \mathrm{~m} \times 2.9 \mathrm{~m}$ PTC aperture dimensions with a $0.16 \mathrm{~m}^{3}$ storage tank volume.

In order to provide thermal comfort conditions, the cooling process has great importance and the cost of energy requirement for the cooling process is very high. In order to reduce the cost of energy requirement for the cooling load, the solar energy is used to supply the energy requirement of the SPAR system. The objective of this study is to analyze the cooling performance of SPAR system used in a dublex-house having the area of $150 \mathrm{~m}^{2}$ with double-glass, light colour shadowing in Isparta Province. A solar powered absoption refrigeration system (SPAR) using $\mathrm{H}_{2} \mathrm{O}$ - $\mathrm{LiBr}$ was designed and analyzed theoretically.

\section{MATERIAL AND METHOD}

\subsection{Basic principle of solar powered absorption refrigeration system}

A solar powered absoption refrigeration system (SPAR) is a kind of vapour compression refrigeration system that solar heat is used to increase the pressure of refrigerant. The absoption refrigeration system using Lithium bromide- water $\left(\mathrm{LiBr}-\mathrm{H}_{2} \mathrm{O}\right)$ consists of solar collector, solution tank, condenser, evaporator, absorber, generator, pump and a heat exchanger. At these sytems, a refrigerant is used to transfer the heat equal to the cooling load from the house to outdoor by the evaporator and an absorbent provides to transport the refrigerant [17]. The refrigerant-absorbent pairs $\left(\mathrm{LiBr}_{-} \mathrm{H}_{2} \mathrm{O}\right)$ are selected by considering both chemical and physical properties of fluids. At this study, $\mathrm{LiBr}-\mathrm{H}_{2} \mathrm{O}$ commonly used in these systems was selected as working fluid pair [18].

At a solar powered absoption refrigeration system (SPAR), the solar heat is used to distill the water vapour from the working solution $\left(\mathrm{LiBr}-\mathrm{H}_{2} \mathrm{O}\right)$ by a generator. The working solution having $\mathrm{LiBr}$ in high quantity passes through the heat exchanger and it is drawn into the absorber. At this time, the vaporized fluid condensed in the condenser by heat transfer to outdoor. The liquid refrigerant having high pressure passes through an expansion valve in order to decrease the pressure of the refrigerant and it is sent into the evaporator. The heat equal to the cooling load of the house is absorbed by the refrigerant in the evaporator and the refrigerant vaporizes. And then, the vaporized refrigerant draws into the absorber and the heat of $\mathrm{Q}_{\mathrm{a}}$ is rejected from the absorber. This weak solution in the absorber is pressured by a solution pump. This solution is passed through a heat exchanger, it returns to the generator and this refrigerant cycle is completed [19]. A shematic presentation of the solar-powered single-effect absorption cooling system using water-lithium bromide $\left(\mathrm{H}_{2} \mathrm{O}-\mathrm{LiBr}\right)$ mixture is shown in Figure 1.

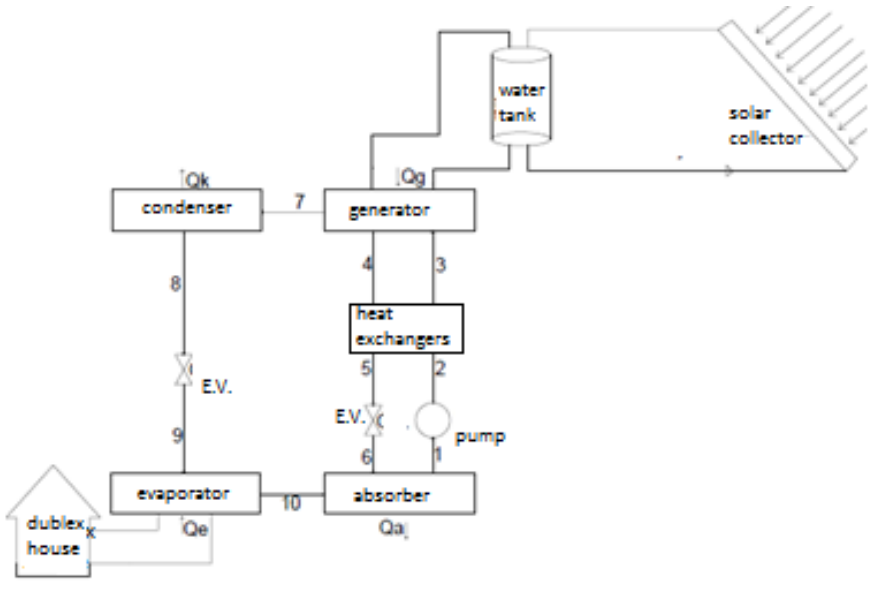

Fig.1. Schematic presentation of the solar-powered single effect absorption cooling system using water-lithium bromide $\left(\mathrm{H}_{2} \mathrm{O}-\mathrm{LiBr}\right)$ mixture

\subsection{Calculation of Cooling Load for a House}

In order to cool a duplex house in Isparta province via a solar powered water-lithium bromide $\left(\mathrm{H}_{2} \mathrm{O}-\mathrm{LiBr}\right)$ absorption refrigeration system, the cooling load of the dublex house 
should be determined. In this study, the considered dublex house is located on a longitude of $30.33^{\circ}$ and $37.46^{\circ}$ latitude. To use at the calculation of cooling load, the meteorological datas for Isparta province are illustrated in Table 1. At this study, the meteorological data of july was used for the calculation of cooling load since the cooling load is maximum in July for Isparta province. The external design temperature was assumed as $30^{\circ} \mathrm{C}$ while the internal design temperature was assumed as $25^{\circ} \mathrm{C}$ and the calculation of cooling load of the house was performed. The floor plan of this duplex house is indicated in Figure 2.

Table1. Meteorological data for Isparta porvince [20-21].

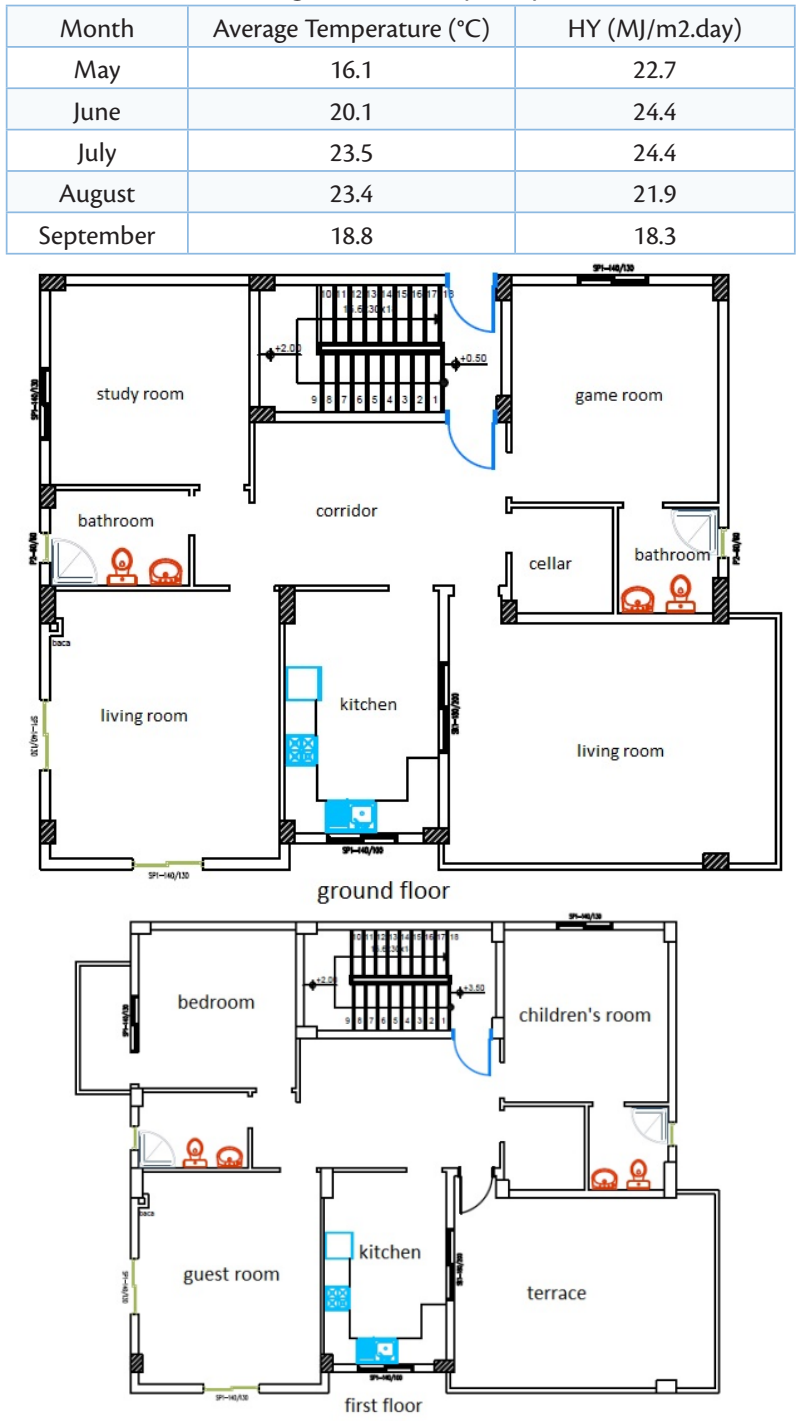

Fig. 2. The floor plan of the duplex house

The ground floor is earth-contacted, each floor area is about $75 \mathrm{~m}^{2}$ and the house has a flat roof. The heat transfer coefficients of the building elements are $1.03 \mathrm{~W} / \mathrm{m}^{2} \mathrm{~K}$ for the outer wall, $2.6 \mathrm{~W} / \mathrm{m}^{2} \mathrm{~K}$ for the double-glazed window, $4.0 \mathrm{~W} /$ $\mathrm{m}^{2} \mathrm{~K}$ for the outer door, $0.58 \mathrm{~W} / \mathrm{m}^{2} \mathrm{~K}$ for the floor and 0.44 $\mathrm{W} / \mathrm{m}^{2} \mathrm{~K}$ for the ceiling [22]. The house is facing to South and there is no obstacle on any sides of the house. The house is well insulated, and it has the normal glass light color shade. While calculating the total cooling load; heat gain from people, lighting and devices, heat gain from neighboring walls, floors and ceilings, heat gain coming from windows by convection and radiation were considered. The total cooling load was calculated using the following formulas [23];

The cooling load for human;

$Q_{i}(W)=$ number ofperson $*$ properties of the house $(w /$ person $)$

The cooling load for fresh air;

$Q_{T H}(W)=$ fresh air per person $\left(m^{3} / h\right)$

* number of person * room factor

Cooling load for lightings and electrical devices;

$$
\begin{aligned}
& Q_{\text {lighting }}(W)=\text { room area }\left(m^{2}\right) * \text { properties of } \operatorname{room}\left(w / m^{2}\right) \\
& Q_{\text {devices }}(W)=\text { numberofdevices } * \text { device properties }(w)
\end{aligned}
$$

Cooling load from radiation;

$$
\begin{aligned}
& Q_{\text {radiation }} \\
& =\text { Window properties }\left(\mathrm{w} / \mathrm{m}^{2}\right) * \text { window area }\left(\mathrm{m}^{2}\right) \\
& * \text { window shadingfactor }
\end{aligned}
$$

Cooling load for convection and conduction;

$\mathrm{Q}_{\text {convectionandconduction }}=8$-12 percentoftotal of coolingloadofhuman, fresh air, lightings, electrical devices and radiation.

Percent quantity at this equation depends on the isolation of the house [6]

Total cooling load;

$$
\begin{gathered}
Q_{\text {total }}=Q_{\text {human }}+Q_{\text {freshair }}+Q_{\text {lightings,electrical devices }}+Q_{\text {radiation }} \\
+Q_{\text {convection }}
\end{gathered}
$$

For Isparta the total cooling load is multipled with 0.89 as the correction factor.

\subsection{Thermodynamic Analysis of Absorption Refrigeration System}

The equations of energy conservation and mass conservation, which are used at the design of the SPAR system, are demonstrated in Table 2. At this table, $\dot{\mathrm{m}}, \mathrm{h}, \dot{\mathrm{Q}}$ and W are identified as the mass flow rate, enthalpy, heat capacity and pump work, respectively. The subscripts of a, g, k and e mean absorber, generator, condenser and evaporator, respectively. The evaporator heat capacity is determined by calculating total cooling load of the house. The thermodynamic calculations of this SPAR system were performed by using evaporator heat capacity and other design parameters shown in Table 3.

Table 2. The equations of energy conservation and mass conservation used at the design of the SPAR system [24]

\begin{tabular}{|c|c|c|}
\hline system eguipments & mass conservation & Energy conservation \\
\hline Absorber & $\dot{\mathrm{m}}_{1}=\dot{\mathrm{m}}_{6}+\dot{\mathrm{m}}_{10}$ & $\dot{\mathrm{Q}}_{\mathrm{a}}=\dot{\mathrm{m}}_{10} \mathrm{~h}_{10}+\dot{\mathrm{m}}_{6} \mathrm{~h}_{6}-\dot{\mathrm{m}}_{1} \mathrm{~h}_{1}$ \\
Pump & $\dot{\mathrm{m}}_{1}=\dot{\mathrm{m}}_{2}$ & $\mathrm{Wp}=\dot{\mathrm{m}}_{2} \mathrm{~h}_{2}-\dot{\mathrm{m}}_{1} \mathrm{~h}_{1}$ \\
Heat exchanger & $\dot{\mathrm{m}}_{2}=\dot{\mathrm{m}}_{3}, \dot{\mathrm{m}}_{4}=\dot{\mathrm{m}}_{5}$ & $\dot{\mathrm{m}}_{2}\left(\mathrm{~h}_{2}-\mathrm{h}_{3}\right)=\dot{\mathrm{m}}_{4}\left(\mathrm{~h}_{4}-\mathrm{h}_{5}\right)$ \\
Generator & $\dot{\mathrm{m}}_{3}=\dot{\mathrm{m}}_{4}+\dot{\mathrm{m}}_{7}$ & $\dot{\mathrm{Q}}_{\mathrm{g}}=\dot{\mathrm{m}}_{7} \mathrm{~h}_{7}+\dot{\mathrm{m}}_{4} \mathrm{~h}_{4}-\dot{\mathrm{m}}_{3} \mathrm{~h}_{3}$ \\
Expansion valve 1 & $\dot{\mathrm{m}}_{5}=\dot{\mathrm{m}}_{6}$ & $\mathrm{~h}_{5}=\mathrm{h}_{6}$ \\
Condenser & $\dot{\mathrm{m}}_{7}=\dot{\mathrm{m}}_{8}$ & $\dot{\mathrm{Q}}_{\mathrm{c}}=\dot{\mathrm{m}}_{8} \mathrm{~h}_{8}-\dot{\mathrm{m}}_{7} \mathrm{~h}_{7}$ \\
Expansion valve 2 & $\dot{\mathrm{m}}_{8}=\dot{\mathrm{m}}_{9}$ & $\mathrm{~h}_{8}=\mathrm{h}_{9}$ \\
Evaporator & $\dot{\mathrm{m}}_{9}=\dot{\mathrm{m}}_{10}$ & $\dot{\mathrm{Q}}_{\mathrm{e}}=\dot{\mathrm{m}}_{10} \mathrm{~h}_{10}-\dot{\mathrm{m}}_{9} \mathrm{~h}_{9}$ \\
\hline
\end{tabular}

Table 3. Design Parameters of Solar-Powered Absorption Refrigeration 


\begin{tabular}{|l|c|c|}
\hline \multicolumn{2}{|c|}{ System } & \multicolumn{2}{c|}{} \\
\hline \multicolumn{1}{|c|}{ Parameter } & Symbol & Value \\
\hline Evaporator & $\mathrm{Q}_{\mathrm{e}}$ & $19,34 \mathrm{~kW}$ \\
Output temperature of evaporator & $\mathrm{T}_{10}$ & $6^{\circ} \mathrm{C}$ \\
Output temperature of solution at the generator & $\mathrm{T}_{4}$ & $90^{\circ} \mathrm{C}$ \\
Concentration of weak solution & $\mathrm{X}_{1}$ & $\% 55 \mathrm{LiBr}$ \\
Concentration of strong solution & $\mathrm{X}_{6}$ & $\% 60 \mathrm{LiBr}$ \\
Steam temperature at the generator & $\mathrm{T}_{7}$ & $85^{\circ} \mathrm{C}$ \\
Output temperature of heat exchanger & $\mathrm{T}_{3}$ & $65^{\circ} \mathrm{C}$ \\
\hline
\end{tabular}

\subsection{Monthly Average of Solar Radiation Reaching to Surface of Inclined Collector and Defination of Collector Area}

The surface area of collector is determined after the generator heat capacity is calculated by the thermodynamic analysis of the SPAR system. While the surface area of collector is defined, the first step is calculation of declination angle. The declination angle is used in order to determine the optimum inclination of plane where the collectors are placed on. Total daily solar radiation reacing to collector surface is assessed by using the mountly average solar radiation $\left(\mathrm{H}_{\mathrm{y}}\right)$ for Isparta Province. The collector efficiency based on collector type is calculated and the required collector area is determined. The corresponding equations are given below: [18]

Declination angle is calculated by the equation (8):

$$
\delta=23.45^{\circ} \sin \left(360 \frac{n+284}{365}\right)
$$

$\mathrm{n}$ means the day of which data is used in a year. The tilt angle of collector is defined as

$$
s_{0}=e-1,5 \delta-\frac{|\delta| e}{180}
$$

Here, e is the latitude angle. Total daily solar radiation reacing to collector surface $\left({ }_{\mathrm{Ht}}\right)$ is calculated by;

$$
\bar{R}=\frac{H_{t}}{H_{y}}
$$

In the equation above, $\mathrm{H}_{\mathrm{y}}$ is the mountly average solar radiation $\left(\mathrm{H}_{\mathrm{y}}\right)$ for Isparta Province. The equation 11 is used to calculate the coefficent $\overline{\mathrm{R}}$;

$$
\bar{R}=\frac{\cos (e-s) \cos \delta \sin H_{g}+\frac{\pi}{180} H_{g} \sin (e-s) \sin \delta}{\operatorname{cosecos} \delta \sin H+\frac{\pi}{180} H \operatorname{sinesin} \delta}
$$

Here, $\mathrm{H}$ is defined as the angle of sunrise and sunset and it is determined by the equation (12);

$$
H=\arccos (- \text { tandtane })
$$

Moreover, $\mathrm{Hg}$ is calculated by the equation (13);

$$
H_{g}=\min [\arccos (-\operatorname{tanetan} \delta), \arccos (-\tan (e-s) \tan \delta]
$$

With the equation (14), the day length is assessed.

$$
t_{0}(\text { saat })=\frac{2}{15} H(\text { derece })=\frac{2}{15} \arccos (- \text { tan } \delta \text { tane })
$$

Daily average solar radiation reaching to surface of inclined collector $\left(\mathrm{I}_{\mathrm{e}}\right)$ is defined as;

$$
I_{e}=\frac{H_{t}}{t_{0}}
$$

After $I_{e}$ is calculated, the surface area of collector $\left(A_{c}\right)$ is de- termined by the equation (16). Here, $\mathrm{Q}_{\mathrm{g}}$ is the generator heat capacity, $\eta$ is the efficiency of the collector system.

$$
A_{c}=\frac{Q_{g}}{\mathrm{\eta} I_{e}}
$$

This efficiency $(\eta)$ is determined as shown below;

$$
\begin{aligned}
& \eta=c_{0}-c_{1} x-c_{2} x^{2} I_{e} \\
& x=\frac{\Delta T}{I_{e}} \\
& \Delta T=T_{\text {ort }}-T_{C}
\end{aligned}
$$

The useful energy acquired by the selected collector is calculated by the following equation;

$$
Q_{f}=\eta A_{c} I_{e}
$$

Some refrigerant systems are designed that the required energy is only obtained from solar energy. On the other hand, some of these systems use both solar energy and electrical energy as supplement energy in order to supply the required energy for SPAR systems [18]. At these systems, the solar fraction (SF) is determined by the equation (21);

$$
S F=1-\frac{Q_{e k}}{Q_{g}}
$$

The supplement energy for a month $\left(\mathrm{Q}_{\mathrm{sp}}\right)$ can be assessed as indicated below;

$$
Q_{s p}=\Delta Q=Q_{f}-Q_{g}
$$

For the SPAR systems using only solar energy, the SF is equal to $100 \%$ [18]. The performance coefficient (COP) of the SPAR systems is defined as;

$$
C O P=\frac{Q_{e}}{Q_{g}}
$$

While determining the collector area for solar powered absorption refrigeration (SPAR) system, the month datas of which cooling loads are high are used. It is concluded that the providing of $70 \%$ and $80 \%$ of annual cooling load by solar energy is economic [25].

\section{RESULTS}

In the present study, a solar-powered absoption refrigeration system (SPAR) using $\mathrm{H}_{2} \mathrm{O}-\mathrm{LiBr}$ was designed and analyzed theoretically to cool a house having the area of $150 \mathrm{~m}^{2}$ with double-glass, light colour shadowing in Isparta Province. The required energy for this SPAR system was supplied by solar energy. The cooling load of the house for july was calculated as $19.34 \mathrm{~kW}$ and details for calculation of cooling load are demonstrated in Table 4.

Table 4. Details of cooling load

\begin{tabular}{|c|c|}
\hline Type of cooling load & Capacity $(\mathrm{W})$ \\
\hline Heat gain due to person & $520 \mathrm{~W}$ \\
\hline Heat gain due to fresh air & $1400 \mathrm{~W}$ \\
\hline Heat gain due to electrical devices and lighting & $14069 \mathrm{~W}$ \\
\hline Heat gain due to Radiation & $1744.72 \mathrm{~W}$ \\
\hline Heat gain due to convection and conduction & $1610 \mathrm{~W}$ \\
\hline Total cooling load (total heat gain) & $19343.72 \mathrm{~W}$ \\
\hline
\end{tabular}

The required cooling load for the house is equal to absor- 
bed heat from the house by the evaporator. The equations of energy conservation and mass conservation shown in Table 2 were used every equipment of the SPAR system and the results were indicated in Table 5. The cooling performance coefficient (COP) of the SPAR systems designed in this study was calculated as 0.72 and the heat capacities of all equipments are given in Table 6.

Table 5. The results of thermodynamic analyses of solar-powered single effect absorption refrigeration system

\begin{tabular}{|c|c|c|c|c|c|c|}
\hline Point & $\mathrm{h}(\mathrm{kJ} / \mathrm{kg})$ & $\mathrm{m}(\mathrm{kg} / \mathrm{s})$ & $\mathrm{P}(\mathrm{kPa})$ & $\mathrm{T}\left({ }^{\circ} \mathrm{C}\right)$ & $\begin{array}{c}\mathrm{X} \\
(\% \mathrm{LiBr})\end{array}$ & State \\
\hline 1 & 83.023 & 0.04137 & 0.934 & 34.9 & 55 & Weak solution \\
\hline 2 & 83.023 & 0.04137 & 9.662 & 34.9 & 55 & Weak solution \\
\hline 3 & 145.38 & 0.04137 & 9.662 & 65 & 55 & Weak solution \\
\hline 4 & 212.191 & 0.03792 & 9.662 & 90 & 60 & Strong solution \\
\hline 5 & 280.217 & 0.04137 & 9.662 & 54.8 & 60 & Strong solution \\
\hline 6 & 280.217 & 0.04137 & 0.934 & 44.5 & 60 & Strong solution \\
\hline 7 & 2627.985 & 0.008315 & 9.662 & 85 & 0 & $\begin{array}{c}\text { Super heated } \\
\text { water vapour }\end{array}$ \\
\hline 8 & 185.207 & 0.008315 & 9.662 & 44.3 & 0 & Saturation water \\
\hline 9 & 185.207 & 0.008315 & 0.934 & 6 & 0 & Saturation water \\
\hline 10 & 2511.798 & 0.008315 & 0.934 & 6 & 0 & $\begin{array}{c}\text { Saturation water } \\
\text { vapour }\end{array}$ \\
\hline
\end{tabular}

Table 6. The equipment capacity of solar-powered absorption refrigeration system

\begin{tabular}{|c|c|c|}
\hline Parameter & Symbol & Capacity \\
\hline Evaporator capacity & $\mathrm{Q}_{\mathrm{e}}$ & $8.02 \mathrm{~kW}$ \\
Pump work & $\mathrm{W}_{\mathrm{ep}}$ & $0.492 \mathrm{~kW}$ \\
Absorber capacity & $\mathrm{Q}_{\mathrm{a}}$ & $38.231 \mathrm{~kW}$ \\
Generator capacity & $\mathrm{Q}_{\mathrm{g}}$ & $26.76 \mathrm{~kW}$ \\
Condenser capacity Solution Heat & $\mathrm{Q}_{\mathrm{k}}$ & $20.32 \mathrm{~kW}$ \\
exchanger & $\mathrm{Q}_{\mathrm{ee}}$ & $6.23 \mathrm{~kW}$ \\
Performance coefficient (COP) & COP & 0.72 \\
\hline
\end{tabular}

The required heat for the generator of SPAR system $(\mathrm{Qg})$ was calculated as $26.76 \mathrm{~kW}$ by the thermodynamic analyses. The inclination of plane that the collectors were placed on was determined as $10.1^{\circ}$. Table 7 displays total daily solar radiation reaching to collector surface $(\mathrm{Ht})$, day length and daily average solar radiation reaching to surface of inclined collector $\left(\mathrm{I}_{\mathrm{e}}\right)$.

Table 7.Total daily solar radiation reaching to collector surface $\left({ }_{\mathrm{Ht}}\right)$, day length (to) and daily average solar radiation reaching to surface of inclined collector $\left(\mathrm{I}_{\mathrm{e}}\right)$

\begin{tabular}{|c|c|c|c|}
\hline Month & $\mathrm{Ht}\left(\mathrm{MJ} / \mathrm{m}^{2}\right.$. day $)$ & to $(\mathrm{h})$ & $\mathrm{le}\left(\mathrm{W} / \mathrm{m}^{2}\right)$ \\
\hline May & 22.5 & 14.02 & 445.82 \\
\hline June & 24.2 & 15.29 & 439.67 \\
\hline July & 24.2 & 15.02 & 447.57 \\
\hline August & 21.7 & 14.09 & 427.83 \\
\hline September & 18.1 & 12.85 & 391.29 \\
\hline
\end{tabular}

The collector surface area was assessed and the results were shown in Table 8. In order to provide the cooling load of this house, the required surface area for the vacuum tube collectors was calculated to be $10.32 \mathrm{~m}^{2}$ while it is found to be $25.95 \mathrm{~m}^{2}$ for the flat plate collectors. It has been concluded that the usage of vacuum tube collector with $57.9 \%$ efficiency is more appropriate since the required collector surface area is $15.63 \mathrm{~m}^{2}$ less than the required collector surface area for flat plate collector. Correspondingly, it is assumed that the cost of the SPAR system with vacuum tube collectors is less than the SPAR system with the flat plate collectors.

Table 8. Type of collectors analyzed in this study

\begin{tabular}{|c|c|c|c|}
\hline Type of collector & $\eta$ & SF & Area $\left(\mathrm{m}^{2}\right)$ \\
\hline $\begin{array}{c}\text { Viessmann Vitesol300T Vacuumtube collector } \\
\text { Optical performance: } 0.809\end{array}$ & & & \\
$\mathrm{k} 1: 1.37 \mathrm{~W} / \mathrm{m} 2 \mathrm{~K}$ & 0.579 & 1 & 10.32 \\
$\mathrm{k} 2: 0.0068 \mathrm{~W} / \mathrm{m} 2 \mathrm{~K}$ & & & \\
\hline $\begin{array}{c}\text { Viessmann Vitesol300F flat plate collector } \\
\text { Optical performance } 0.834\end{array}$ & & & \\
$\mathrm{k} 1: 3.66 \mathrm{~W} / \mathrm{m} 2 \mathrm{~K}$ & 0.231 & 0.999 & 25.95 \\
$\mathrm{k2}: 0.0169 \mathrm{~W} / \mathrm{m} 2 \mathrm{~K}$ & & & \\
\hline
\end{tabular}

\section{CONCLUSION}

In the present study, cooling of a duplex house placed in Isparta province has been aimed by using solar-powered single effect absorption refrigeration system operating water-lithium bromide $\left(\mathrm{H}_{2} \mathrm{O}-\mathrm{LiBr}\right)$ solution. The main objective of this study was to provide a decrease in the cost of energy requirement for the cooling process. Firstly, the cooling load of the house was determined as $19.34 \mathrm{~kW}$. The heat required for the generator in order to provide the cooling load of the house $(19.34 \mathrm{~kW})$ was calculated as $26.76 \mathrm{~kW}$, and the required collector surface area was determined by considering different types of collectors (flat plate and vacuum tube) to meet this heat capacity. In order to provide the cooling load of this house, the required surface area for the vacuum tube collectors was calculated to be $10.32 \mathrm{~m}^{2}$ while it is found to be $25.95 \mathrm{~m}^{2}$ for the flat plate collectors. It has been concluded that the useage of vacuum tube collector with 57.9\% efficiency is more appropriate since the difference between the required collector surface area of vacuum tube collector and flat plate collector was determined as $15.63 \mathrm{~m}^{2}$.

\section{REFERENCES}

[1] Daşkın M., Aksoy I.G. 2014. Iklimlendirme Amaçlı Güneş Enerjisi Destekli Bir Absorbsiyonlu SoğutmaSisteminin Simülasyonu, Batman Üniversitesi Yaşam Bilimleri Dergisi, 4 (1): 52-65.

[2] Dinçer İ., Erdallı Y. 1993. Absorbsiyonlu Soğutma Sistemlerinin Rolü ve Etkinliği, Termodinamik Dergisi, 5: 31-37.

[3] Büyükalaca O., Yılmaz T. 2003. Güneş Enerjisi ile Soğutma Teknolojilerine Genel Bir Bakış, Tesisat Mühendisliği Dergisi, Mayıs-Haziran, 3: 45-56.

[4] Pastakkaya B., Ünlü K., Yamankaradeniz R. 2008. Isıtma ve Soğutma Uygulamalarında Güneş Enerjisi Kaynaklı Absorbsiyonlu Sistemler, TTMD Dergisi, 57: 25-32.

[5] Yılmazoğlu M.Z., 2010. Tek Etkili Bir Absorbsiyonlu Soğutma Sisteminin Termodinamik Analizi, Gazi Üniversitesi Mühendislik Mimarlık Fakültesi Dergisi, (25):2

[6] Öztürk İT. 2006. Güneş Enerjisinden Absorbsiyon Teknolojisi Yardımı ile Güç Üretimi, Mühendis ve Makine, 563 (47): 17-23.

[7] Ghaddar N.K., Shihab M. and Bdeir F. 1997. Modelling and simulation of solar absorption system performance in Beirut, Renew. Energy $10(4), 539-558$

[8] Şahin B., Bilgili M., Çetingöz A., Kurtulmuş N. 2016. Performance Analysis of Solar Powered AbsorptionRefrigerationSystemfor Mersin Province, Çukurova Üniversitesi Mühendislik Mimarlık Fakültesi 
Dergisi, Adana, 31 (1): 371-379.

[9] Li M., Xu C., Hassanien R.H.E., Xu Y., Zhuang B. 2016. Experimental investigation on the performance of a solar powered lithium bromide-water absorption cooling system, Int. J. Refrig., 71: 46-59.

[10] Florides, G.A.,Kalogirou, S.A., Tassou, S.A., Wrobel, L.C. 2002. Modelling, Simulation of an Absorption Solar CoolingSystem of Cyprus, Solar Energy,72: 43-51.

[11] Xu S.M., Huang X.D., Du R.. 2011. An investion of Solar Powered Absorbtion Refrigeration System with advanced energy storage technology, Solar energy, 85:1794-1804.

[12] Ali A.H.H., Noeres P. and Pollerberg C. 2008. Performance Assessment Of An Integrated Free Cooling and Solar Powered Single-Effect Lithium Bromide-Water Absorption Chiller.Solar Energy,82:1021-1030.

[13] Ramesh R, Murugesan S.N.., Narendran C and Saravanan R. 2015. Cascaded Energy Plant Using Amonia Absorption Refrigeration System For Combined Cooling And Heating Applications. Science and Technology For The Built Environment, 21:290-299.

[14] Bozkaya B. Ve Akdemir Ö. Güneş Enerjili NH3-H2O Absorpsiyonlu Soğutma Sisteminin İzmir Ili İçin İncelenmesi, X. Ulusal Tesisat Mühendisliği Kongresi,1405-1413.

[15] Özay F.l., 2008. NH3-H2O Absorbsiyon Soğutma Sisteminin Güneş Enejisi Ille Çalıştırılması Ve Verimlilik Analizi,Süleyman Demirel Ünivesitesi Fen Bilimleri Enstitüsü Yüksek Lisans Tezi.lsparta.

[16] Stanciu C., Stanciu D. and Gheorghian A-T. 2017. Thermal Analysis of a Solar Powered Absorption Cooling System with Fully Mixed Thermal Storage at Startup, Energies, 10 (72);1-19 doi:10.3390/ en10010072

[17] Yamankaradeniz R., Horuz I., Coşkun S. 2002. Soğutma Tekniği ve Uygulamaları, Vipaş A.Ş., 608s. Bursa.

[18] Goralı E. 2007. Güneş Enerjili Absorbsiyonlu Soğutma Sistemi, İstanbul Teknik Üniversitesi, Enerji Enstitüsü, Yüksek Lisans Tezi, 70s. Istanbul.

[19] Yakut A.K., Şahin Şencan A., Selbaş R., Dikmen E., Görgülü B., Dostuçok I., Kutlu S. 2013. Güneş Enerjisi Destekli Absorbsiyonlu Soğutma Sisteminin Termodinamik İncelenmesi, Soğutma Dünyası, Ocak-Şubat-Mart, 16 (60): 76-81.

[20] MGM.2018. https://www.mgm.gov.tr/?il=Mersin, (Erişim Tarihi: 25.04.2018).

[21] YEGM. 2018. http://www.yegm.gov.tr/MyCalculator/pages/33.aspx, (Erişim Tarihi: 25.04.2018).

[22] Kent E.F., Kaptan I.N. 2009. İzmir Illindeki Elli Yataklı Bir Otel için Güneş Enerjisi Destekli Isıtma ve Absorbsiyonlu Soğutma Sisteminin Teorik Incelenmesi, IX. Ulusal Tesisat Mühendisliği Kongresi, 06-09 Mayıs, 163-170, İzmir.

[23] Canovate enerji. 2018. http://portal.canovateenerji.com/trTR/sogutma-yuku-hesabi/ (Erişim Tarihi: 25.04.2018).

[24] Yalçın R.Ç. 2012. Bir Absorbsiyonlu Soğutma Sisteminin Isıl Analizi ve Tasarımı, Dokuz Eylül Üniversitesi, Makine Mühendisliği Bölümü, Termodinamik Anabilim Dalı, Yüksek Lisans Tezi, 77s. İzmir.

[25] Henning H.M. 2004. Solar-Assisted Air-Conditioning in Buildings, Springer Press. 